\title{
Effectiveness of National Bank of Ethiopia in Choosing Appropriate Intermediate Target
}

\author{
Dawit Hayeso Borsamo ${ }^{1}$, Dr. Parmod Kumar Aggarwal ${ }^{2}$ \\ ${ }^{I}$ Ph.D. Research Scholar in Department of Economics, Punjabi University, Patiala, India. \\ ${ }^{2}$ Ass.Professor and PhD. Supervisor in Department of Economics, Punjabi University, Patiala, India. \\ ** This paper is a part of Ph.D. thesis titled "Effectiveness of Monetary Policy in Ethiopia"
}

\begin{abstract}
The study assesses the effectiveness of National Bank of Ethiopia in choosing appropriate intermediate targeting framework by examining the stability of long run money demand function from 1981 to 2014. To examine the stability of money demand the study used real gross domestic product (RGDP) as scale variable, saving deposit rate (Rt) as opportunity cost variable, average exchange rate (Ex) as indicator of openness of economy, and real money demand measured by $\left(M 2 / P_{t}\right)$.The study used $A D F$ unit root test, the Johansen and Juselius (1990) Co-integration, error correction model (ECM), and CUSUM and CUSUMSQ stability tests. The results of long run regression indicated that real broad money demand had positive and highly significant relationship with RGDP and exchange rate whereas saving interest rate has negative and insignificant relationship. In addition CUSUM and CUSUMSQ stability tests of long run money demand function showed the evidence for parameter stability. However, the short run model indicated instability of the parameters. Thus, monetary targeting framework based on broad money supply (M2) can be appropriate intermediate target of monetary policy in Ethiopia. This implies that national Bank of Ethiopia is Effective in choosing intermediate monetary policy target. In short run, however, monetary policy authority can better target multiple macroeconomic indicators.
\end{abstract}

Keywords: money demand, Stability, intermediate target

\section{Introduction}

The effectiveness of monetary policy is inextricable linked to the appropriateness of intermediate target chosen by central bank. The choice of intermediate target is often between money supply and interest rate. However, central banks cannot choose both of them at the same time. As a result, monetary policy authority adopts either money supply or interest rate as intermediate target of monetary policy framework. Moreover, the adoption of effective intermediate target requires the knowledge about money demand function and its stability so that money supply can serve as an appropriate intermediate target of monetary policy framework. Poole (1970, [1]), Mishkin (2004, [2]), Friedman (1975, [3]) and Volcker (1978, [4]) recommended money supply as intermediate target of monetary policy when the money demand function is stable and investment function is unstable.

In the 1970s, monetary targeting was adopted by several countries, notably Germany, Switzerland, Canada, United Kingdom, and Japan, as well as in the United States. This strategy involves using monetary aggregates as an intermediate target to achieve ultimate objectives of monetary policy. Since 1980s, however, most of developing countries had liberalized their economy in the light of global development. The financial liberalization measures taken in developing countries had raised the question about the stability of money demand and appropriateness of money supply as an intermediate target of monetary policy. In addition the increasing openness of the economy and associated financial flow had challenged the position of central banks to maintain money supply at desired level. Consequently, central banks of many developing countries had shifted their monetary policy strategies from monetary targeting to multiple indicators approach, interest rate or inflation targeting. The justification of their shift is that financial liberalization and economic reform measures might have contributed to the instability of money demand function (Mohanty, 2012, [5]).

Following the shift made by these countries, a number of the studies were made in different countries to ascertain whether the money demand function had remained stable over these periods. Faridi and Akhtar (2013, [6]) empirical evaluated the stability of money demand function in Pakistan for the period 1972 to 2011. Their finding indicated that money demand function had remained stable for the period under consideration. Similarly, the study made by John,Soni and Matthew(2013, [7]) in Nigeria, Bhatta (2013, [8]) in Nepal and Inoue and Hamori(2008, [9]) in india, showed the evidence for stable long run money demand function. However, the study made by Jiranyakul and Opiela (2014, [10]) in Thailand, Sarwar,Sarwar and Waqas( 2013, [11]) in Pakistan found the evidence for the instability of money demand function.

In Ethiopia, Since 1990s, the government has been taking progressive financial and economic reform measures in view of increasing the efficiency of the economy. Despite the change in economic structure and 
liberalization measures National Bank of Ethiopia has adopted broad money supply (M2) as intermediate target in monetary targeting framework of 2009. Since then it has continued to use broad money supply as intermediate target of its monetary policy framework. However, very few studies, Kibret (2003, [12]) and Sterken $(1999,[13])$ were made to assess the appropriateness of broad money supply as intermediate target of monetary target framework for Ethiopia.

Therefore, this study assesses the effectiveness of National Bank of Ethiopia in choosing appropriate intermediate targeting framework by examining the stability of long run money demand function from 1981 to 2014. This study differs from recent work on this topic as it focus on the use of appropriateness of broad money supply as intermediate targets than end outcome orientation to evaluate effectiveness of monetary policy. The purpose of this study is to fill the previous gap left by other studies in determining the long run relationship between real broad money demand and its determinants. The findings of the analysis are also expected to help monetary policy authority of Ethiopia in devising monetary policy strategies.

To achieve the objectives of the study the study used Johansen (1988, [14]) and Johansen and Juselius (1990, [15]) co-integration approach in conjunction with error correction model (ECM). Before parameter estimation time series properties of all variables was checked using Augmented Dickey-Fuller (ADF) unit root test. After checking time series properties of all variables, the estimation of parameters was done using ordinal least square (OLS) method. The statistical validity of the results was ascertained using t-statistics, coefficient of determination $\left(\mathrm{R}^{2}\right)$, F-statistics and Durbin-Watson statistics. It has been noted that effectiveness of adopting the appropriate intermediate target depends on the stability of the money demand function. Consequently, the stability test was applied to the residuals of the long run and short run models with the help of the cumulative sum (CUSUM) and the cumulative sum of squares (CUSUMSQ) tests introduced by Brown, Durbin, and Evans $(1975,[16])$.

The study is organized in four sections: the first section is introduction, the second section presents overview of the monetary policy approaches, and third section provides model specification, data, and econometrics methods. Section four reports empirical results, whereas the last section presents Conclusions of the study.

\subsection{Definition and Objectives of monetary policy}

\section{Overview of the Monetary Policy Approaches}

Nnanna (2001, [17]) defined monetary policy as a course of actions taken by central banks to regulate the value, supply and cost of money in economy to achieve predefined macroeconomic objectives. The objective of monetary policy varies from country to country. In India, objective of monetary policy is to maintain price stability and ensuring adequate flow of credit to productive sectors. In Nigeria the objectives are to ensure price stability, maintain external reserve and promote sound financial system. The objectives monetary policy is derived from the respective tasks mandated to central bank. The task is commonly specified in the central bank law. It ranges from a single objective of price stability to multiple objectives of growth and financial stability (Mohanty,2011, [18]). It is the achievement of these objectives that inform the importance of monetary policy. Therefore, monetary policy framework should be devised in such away to achieve macroeconomic objectives. When those two are congruent, the monetary policy framework is considered welldefined (Anwar, 2012, [19]).

The commencement of monetary policy in Ethiopia goes back to the establishment of National Bank of Ethiopia (NBE) in 1963. Since then, the objectives of monetary policy have undergone various changes due to the change in regimes and subsequent change in economic principles. In 1974, the revolutionary Marxist army committee- Derg seized the power and adopted socialism as national policy of Ethiopia. Consequently, 1976 monetary and banking proclamation No.99/1976 came into force to shape the NBE's role according to the socialist economic principles. The purpose of NBE under this proclamation was to foster balanced and accelerated economic development, promote and maintain high level production, and promote full development of production forces of Ethiopia (Gidey, 1997, [20]). Thus, national bank of Ethiopia was an instrument in the building the economy in socialist line of production.

Following the downfall of the Derg regime in 1991, Ethiopian People's Revolutionary Democratic Front (EPRDF) seized power. The new regime has adopted the principle of Market economy with vast economic reform and financial liberalization. Since then Ethiopia has experienced strong economic growth accompanied by mounting macroeconomic pressures and inflation challenges (Neube,Lufumpa, and Ndikumana, 2010, [21]). The need for stable price and healthy financial system necessitated the amendment of national bank law in 2008. The amended Proclamation No. 591/2008 paved the way to formulate sound and comprehensive monetary policy strategies. According to the amended Proclamation, the purpose of the National Bank is to maintain stable rate of price and exchange, to foster a healthy financial system and to undertake such other related activities as are conducive to rapid economic development of Ethiopia. 


\section{Price Stability}

Since 1990s, policymakers in the Ethiopia increasingly become aware of the social and economic costs of inflation. Indeed, price stability is increasingly viewed as the most important objective of monetary policy. Price stability is desirable because a rising price creates uncertainty about the future profitability of investments which might hamper economic growth. For advanced economies, an inflation rate of about 1-3 per cent is considered as a proxy for macroeconomic stability and for emerging and developing economy 11-12 percent can be considered as appropriate (Mohanty,2010, [22]).

\section{Exchange Rate stability}

The main argument in favour of stable exchange rate regimes is the ability of such regimes to induce price discipline and commitment to effectiveness of monetary policy. In addition stable exchange rate will increase credibility of central bank through its commitment to low inflation expectations. Thus, exchange rate stability became crucial for inflation management as a stable exchange rate is expected to reduce domestic inflation pressures through a policy discipline effect and credibility effect. Policy discipline effect working on money supply growth, through which exchange rate regime may ultimately influence (Mohanty and Bhanumurthy, 2014, [23]). Thus, literature on the assessment of the optimal exchange rate regime favours stable exchange rate. Stable exchange rate is considered less inflationary than a more flexible regime as it has a restrictive impact on the determinants of inflation such as money supply and money demand.

\section{Promoting healthy financial system}

Financial stability means the ability of the economy to absorb shocks and maintain confidence in financial system. Threats to financial stability can come from internal and external shocks. Such shocks can destabilize the country's financial system and can interfere with the ability of financial markets to channel funds to people with productive investment opportunities (Kinight, 1998, [24]). While a low level of inflation is essential to sustain high levels of growth, it is not sufficient to maintain financial stability. Besides price stability, ensuring orderly conditions in the financial system has become a key policy concern. Thus, financial stability had emerged as another important objective of monetary policy in Ethiopia.

Thus, monetary policy in Ethiopia has evolved to have multiple objectives of price stability, Exchange Rate stability and financial stability. These objectives are not inherently contradictory, rather mutually reinforcing. Price and exchange rate stability, and healthy financial systems are important for sustaining high economic growth and development which is the ultimate objective of public policy.

\subsection{Strategies of monetary policy}

Central banks attain its monetary policy objectives by using monetary policy instruments which is under its control. However, these instruments do not directly affect monetary policy objective. Moreover, the effect of the policy on objective variable can only be observed after the policy has been pursued for some time. Consequently, the action of monetary policy cannot be evaluated before the effects have been observed after some periods (Mishkin, 2004). Due to these problem central banks uses intermediate target to appraise stance of its policy actions. Intermediate variables are closely related with the objectives of monetary policy and readily affected by the policy instruments. The use of intermediate target helps monetary policy authority to judge whether its policies are on the right track, rather than waiting for final outcome of its policies.

A central feature of monetary policy strategies in all countries is the use of a nominal anchor as an intermediate target to achieve the ultimate objectives of monetary policy. There are various variables with potential to serve as intermediate targets. An ideal intermediate target must be measurable, controllable and have a predictable relationship with the ultimate objective of monetary policy (Davis, 1990 [25]). This last requirement allows the central bank to explain its policy actions and expected outcomes.

Gichuki, Oduor and Kosimbei (2012, [26]) suggested that interest rate and money supply as intermediate targets of monetary policy framework. However, even these intermediate targets are not directly affected by the central bank's policy tools. Central bank influences the intermediate target indirectly through operating targets. Policy makers will adjust their operating targets such as monetary base and short run interest rates which are more responsive to instruments (Mishkin, 2004). Thus, the conduct of monetary policy can be systematically represented as follows: 


\begin{tabular}{|c|c|c|c|}
\hline $\begin{array}{l}\text { Monetary policy } \\
\text { Instruments } \\
\text { - Open Market Operations } \\
\text { - Reserve Requirements } \\
\text { - Ovemight Rate and Bank } \\
\text { Rate, Repo and reverse } \\
\text { Redo }\end{array}$ & $\begin{array}{l}\text { Operating targets } \\
\text { - Monetary Base or } \\
\text { high powered } \\
\text { money } \\
\text { - Short Run Interest } \\
\text { Rate }\end{array}$ & $\begin{array}{l}\text { Intermediate } \\
\text { Targets } \\
\text { - Monetary } \\
\text { Aggregates } \\
\text { - Short Run and } \\
\text { Long Run } \\
\text { Interest rates }\end{array}$ & $\begin{array}{l}\text { Final objectives } \\
\text { - Price Stability } \\
\text { - Economic Growth } \\
\text { - Financial Stability } \\
\text { - Full employment } \\
\text { - Exchange rate } \\
\text { stability etc. }\end{array}$ \\
\hline
\end{tabular}

Chartl:- strategies of monetary policy

To achieve monetary policy objectives of price and exchange rate stability and support of sustainable economic growth, the NBE sets broad money supply (M2) as an intermediate target. The bank hits intermediate targets by using growth of base money/reserve money as operational targets. The instruments used by NBE include reserve requirements, open market operations, central bank standing credit facility, setting minimum deposit rate, Direct borrowing/lending in the inter-bank money market, selective credit control, and moral suasion (NBE,2009, [27]).

\subsection{Choice of intermediate targets}

The choice of intermediate target of monetary policy is a disputed matter in economics. The choice of is often between monetary aggregates and interest rates. Due to inverse relationship between interest rates and money supply, they cannot be used simultaneously. Therefore, central bank is forced to choose either money supply or interest rates as intermediate target. In the 1970s, monetary targeting was adopted by several countries, notably Germany, Switzerland, Canada, the United Kingdom, and Japan, as well as in the United States. This strategy involves using monetary aggregates as an intermediate target to achieve ultimate objectives of monetary policy. A major advantage of monetary targeting is that it enables a central bank to choose goals for inflation that may differ from those of other countries and allows some response to output fluctuations. Thus, monetary targets can send almost immediate signals about the stance of monetary policy helping to constrain the monetary policy authority from falling into the time consistency trap (Mishkin, 2004).

Poole (1970) argued that monetary target should be used when the demand for money is stable and investment-saving function is unstable ; otherwise interest rates is considered as the appropriate intermediate target. Friedman (1975) also argued that central bank has effective control over money supply than rate of interest. Consequently they argued for the use of monetary targeting as intermediate target of monetary policy strategy. They also argued that interest rate is affected by various macroeconomic factors which are beyond the control of central banks. Thus, they indirectly showed inappropriateness of interest rate as intermediate target and proposed a constant growth rate of money supply as appropriate intermediate target. Volcker (1978) also argued that the impact of central banks action on real interest rate is ambiguous. The magnitude of interest rate in the economy is affected by inflation expectation and other factors that affect the expectation of economic agents. The use of Interest rates as intermediate target of monetary policy strategy could give false signals on the happenings of the real sector of the economy. Thus, he proposed money supply as intermediate target as the relationship between money and inflation is readily understood.

Despite Many studies conducted to assess the appropriateness of intermediate targets unfortunately the economic literature has not yet arrived at a concession as to which target should be used. However, the discussion made so far reveals that the stability of the money demand function is prerequisite to choose monetary aggregate as intermediate target of monetary policy framework.

In monetary targeting framework of 2009, National Bank of Ethiopia adopted broad money supply (M2) as intermediate target (NBE, 2009). It targets the growth of broad money supply (M2) consistent with targets for inflation, economic growth and balance of payments, while allowing reasonable credit growth to the productive sectors of the economy. However, very few studies have been undertaken to examine the appropriateness of target chosen for monetary framework. Therefore, this study attempts to analyse the effectiveness of appropriateness of National Bank of Ethiopia in choosing the appropriate intermediate by examining the stability of money demand function for the period 1981 to 2014.

\subsection{Theory of money demand}

Theoretical explanation of money demand and its stability has been a subject of controversy among the classical school, Keynesian and Milton Friedman's modern quantity theory which are discussed below.

\subsubsection{Classical theory of money demand}

The classical economists did not explicitly formulate demand for money theory but their views are inherent in the quantity theory of money. In classical economy money is considered as a medium of exchange whose value is independent of transaction level in the economy. The most important feature of this theory is that 
it suggests interest rates have no effect on the demand for money. The clarification of classical theory of money demand is reflected in Irving Fisher equation of exchange presented by Fisher (1911, [28]):

$$
\mathrm{MxV}=\mathrm{PxY}-------------------1
$$

Where $\mathrm{M}$ is quantity of money; $\mathrm{V}$ is velocity of money; $\mathrm{P}$ is price level in the economy; and $Y$ is aggregate real income. The equation of exchange thus states that the quantity of money multiplied by the number of times this money is spent in a given year must be equal to nominal income. Irving Fisher reasoned that velocity is determined by the institutions in an economy that affect the way individuals conduct transactions. He took the view that the institutional and technological features of the economy would affect velocity only slowly over time, so velocity is reasonably constant in the short run. Fisher's view that velocity is fairly constant in the short run transforms the equation of exchange into the quantity theory of money, which states that nominal income is determined solely by movements in the quantity of money. Since the classical economists assumed complete flexibility of price and full-employment level, quantity theory of money tells us how much money is held for a given amount of aggregate income which is in fact a theory of the demand for money. Dividing both sides of the equation of exchange by $V$, the equation can be rewriting as:

$$
M=1+\frac{1}{V} x P Y----------------2
$$

When the money market is in equilibrium, the quantity of money $\mathrm{M}$ that people hold equals the quantity of money demanded $\mathrm{M}^{\mathrm{d}}$, so replacing $\mathrm{M}$ in the equation by $\mathrm{M}^{\mathrm{d}}$. Using $\mathrm{k}$ to represent the quantity $1 / V$ classical money demand function is written as:

$$
M^{d}=1+k \times P Y----------------3
$$

Therefore, Fisher's quantity theory of money suggests that the demand for money is purely a function of income, and interest rates have no effect on the demand for money (Mishkin, 2004).

\subsubsection{Keynesian theory of money demand}

In his famous 1936 book The General Theory of Employment, Interest, and Money, John Maynard Keynes abandoned the classical view that velocity was a constant and developed a theory of money demand that emphasized the importance of interest rates. According to Keynes $(1936,[29])$ the total demand for money means total real cash balances (M/P) hold by individual for the purpose of meeting transaction, precautionary, and speculative motives. The transactions demand for money arises from the medium of exchange function of money in making regular payments for goods and services. In addition to holding money to carry out current transactions, people hold money as Precautionary demand against an unexpected need. Keynes believed that the amount of money balances people want to hold as Transactions and precautionary demand depends on the level of income. Where as Speculative demand arises from the need for cash to take advantage of investment opportunities that may arise and affected by interest rate. Putting the three motives for holding money balances together, Keynesian money demand function can be given as:

$$
\frac{M t}{P t}=f(Y t, R t)-------------------(4)
$$

Where, Mt represents nominal money supply for period $t$; Pt represents the price index for period $t$; Yt represents output for period $\mathrm{t}$; and Rt represents the interest rate for period $\mathrm{t}$.

According to Keynesian Increases in output bring increases in money demand, and increases in interest rates bring decreases in money demand. In other word, demand for money is positively related to income and negatively related to the level of interest rate.

\subsubsection{Friedman's modern quantity theory of money}

In 1956, Milton Friedman developed a theory of the demand for money in article, "The Quantity Theory of Money: A Restatement." Friedman (1956, [30]) asserted that the quantity theory of money is no more as a theory of money demand not a theory of output, income or prices. He argued that the velocity of money is highly predictable and that the demand for money function is highly stable. In his restatement money is demanded for transaction purposes and an asset or a part of wealth. The money demand expressed by real cash balance $(\mathrm{M} / \mathrm{P})$ as commodity is a function of permanent income of money holder, relative expected rate of return from bonds, stocks and money, and expected inflation rate. According to him, the demand for real money balances increases when permanent income increases and declines when the expected returns on bonds, stocks, or goods increases versus the expected returns on money, which includes both the interest paid on deposits and the services banks provide to depositors.

DOI: 10.9790/5933-0801035971 $\quad$ www.iosrjournals.org $\quad 63 \mid$ Page


In contrast to Keynes, Friedman viewed money and goods as substitutes; that is, people choose between them when deciding how much money to hold. Unlike Keynes's theory, which indicates that interest rates are an important determinant of the demand for money, Friedman's theory suggests that changes in interest rates should have little effect on the demand for money (Mishkin, 2004)..

\subsection{Stability of money demand function}

The stability of the money demand function gives a signal to central bank whether it should target interest rates or money supply. If the money demand function is unstable as Keynes thought, then velocity is unpredictable, and the quantity of money may not be tightly linked to aggregate spending. Hence, money supply cannot be used as intermediate target of monetary policy (Mishkin, 2004). Rangarajan (1997, [31]) argued that the stable money demand function would provide the necessary ground for the use of money supply as intermediate targets. They suggested that Stable money demand gives money supply better predictable effects on interest rates, output, and inflation. Thus, this section examines the empirical evidence on the stability of money demand function as it has important implications to choose effective intermediate target.

Bhatta (2013) empirically evaluated the existence of a stable long-run money demand function in Nepal using annual data over the period 1975-2009. He used auto regressive distributive lag (ARDL) approach to co-integration. The finding of his study indicated the existence of long run relationship between Real money balance, real GDP and interest rate. The study also revealed the stable money demand suggesting that monetary aggregate can serve as an Intermediate target of monetary policy strategy.

Faridi and Akhtar (2013) employed bound testing approach to co-integration to estimate factors that determine real money demand function in Pakistan .The study cover the period from 1972 to 2011. The findings of their study showed that income elasticity is positive while interest and exchange rate elasticity is negative. They had also indicated that demand for money function is stable both for long and short run.

Similarly, the study made by John,Soni and Matthew(2013) in Nigeria, and Inoue and Hamori(2008) in india, have examined the stability of money demand function in the context of co-integration analysis. Their study showed the evidence for stable long run relationship between monetary aggregates and its determinats. Thus they concluded that money supply could provide correct signals for monetary policy formulation. However, the study made by Jiranyakul and Opiela (2014) in Thailand, Sarwar,Sarwar and Waqas( 2013) in Pakistan found instability in money demand function.

The recent instability of the money demand function calls into question whether the economic theories and empirical analyses are adequate. As a result, the study attempted to assess whether the money demand function in Ethiopia has remained over the time.

\subsection{Model specification}

\section{Model Specification, Data and Econometrics Methods}

Based on conventional monetary policy theory and empirical studies econometric model was developed to estimate long run relationship and short run dynamics of money demand function. The Model begins by standard specification of Keynesian money demand function by assuming a linear econometric relationship which is expressed as:

$$
\frac{\mathrm{Mt}}{\mathrm{Pt}}=\mathrm{f}(\mathrm{Yt}, \mathrm{Rt})--------------------(5)
$$

Where, $\frac{\mathrm{Mt}}{\mathrm{Pt}}$ represents real money balance for period $\mathrm{t}$;Mt broad money supply, Pt consumer price index for period $\mathrm{t}$; and Rt Average saving rate as proxies for the opportunity costs of holding money, Yt represents real income for period $t$ and Real gross domestic product (RGDP) is used as proxy variable for Real income.

Considering the above assumption and taking natural logarithm, the linear specification of long-run money demand function is given as:

$$
\operatorname{Ln}\left(\frac{\mathrm{Mt}}{\mathrm{Pt}}\right)=\beta \mathrm{o}+\beta 1 \ln R G D P+\beta 2 \ln R \mathrm{t}+\mathrm{U}_{\mathrm{t}}-----------(6)
$$

Where $\mathrm{U}_{\mathrm{t}}$ is error term

Following the recent study made by Nduka, Chukwu and Nwakaire(2013) the openness of the economy is incorporated into the money demand function using expected average exchange rate depreciation (Ex). The reason for the inclusion of exchange rate into money demand function is that NBE follows managed exchange rate system where any fluctuation of the exchange rate may influence the demand for money. Thus, the exclusion of the exchange rate may cause misspecification biases in the money demand function. By 
incorporating expected exchange rate depreciation and replacing $\frac{M t}{P t}$ by real broad money supply based on M2 (RM2), real money demand function is expressed as:

$$
\operatorname{LnRM} 2=\beta \mathrm{o}+\beta 1 \ln R G D P+\beta 2 \operatorname{lnRt}+\beta 3 \ln E x+\mathrm{U}_{\mathrm{t}}-----------------(7)
$$

Following the literature on demand for money and the conventional economic theory, $\beta 1>0, \quad \beta 3>0$. and $\beta 2<0$. Thus, the appropriateness of monetary targeting framework depends to a large extent on the stability of the money demand function estimated above.

After checking time series properties of variables, the estimation of parameters was done using ordinal least square (OLS) method and its statistical validity was ascertained using t-statistics, coefficient of determination $\left(\mathrm{R}^{2}\right)$, F-statistics and Durbin-Watson statistics. The t-statistics were used to test individual significance of the parameters, $\mathrm{R}^{2}$ to test the explanatory power of the model, and F-statistics to test the overall significance of the model. Finally, the existence of serial autocorrelation was tested using the DurbinWatson statistics.

\subsection{Data type and sources}

The empirical work outlined below used annual data for the period from 1981 to 2014. The choice of the period for analysis is constrained by the availability of time series data on the variables included in the model. The variables included in the model are real broad money supply (M2/ CPI), real gross domestic product (RGDP), average saving deposit rate (Rt), and average exchange rate (Ex). Data on broad money supply (M2) and average saving deposit rate (Rt) were collected from NBE. The data on consumer price index (CPI, base year 2010/11=100)) and average saving deposit rate (Rt) is extracted from various issues of the NBE Bulletin. Average exchange rate $(\mathrm{Ex})$ is extracted from Ethiopian Economic association database and NBE Bulletin. All series are expressed in natural logarithms.

\subsection{Econometric Methods}

The study employed Johansen and Juselius (1990) co-integration method and error correction method (ECM) to check long-run relationship and short run dynamics of money demand function. It also used ADF unit root test to evaluate time series prosperities of variables included in the model. In addition CUSUM and CUSUMSQ stability tests of parameter estimates were also used to ascertain the stability of money demand function over the time.

\subsubsection{Unit root test}

Most time series macroeconomic variables are non-stationary over time. Consequently stationarity of variables included in the model was examined using Augmented Dickey-Fuller (ADF) unit root tests. The equation for Augmented Dickey Fuller (ADF) test is given as follows:

$$
\Delta Y_{t}=\alpha_{1}+\alpha_{2} t+\delta Y_{t-1}+\sum_{p=1}^{n} Y_{t-p}+\mathrm{U}_{\mathrm{t}}---------------(8)
$$

$Y_{t}$ is any variable in the model to be tested for stationary, $\mathrm{U}_{\mathrm{t}}$ is an error term, $\Delta$ is the first difference operator, $\alpha_{1}$ is a constant, $\alpha_{2}$ is coefficient of a trend, $\mathrm{t}$ is trend and $\delta=\gamma-1$.

Thus, the basic objective of Augmented Dickey-Fuller (ADF) is to test:-

Null hypothesis: H0: $\delta=0$, there is unit root and time series in non-stationary against, Alternative hypothesis: Ha: $\delta<0$, there is no unit root and time series is stationary

\section{Decision Rule}

Accept H0: if calculated t-statistics value less than ADF critical t- value at $5 \%$ significance level

Reject H0: if calculated t-statistics value greater than ADF critical t- value at $5 \%$ significance level

As the tests are sensitive to the choice of lag length, the optimal lag length was chosen using Akaike Information Criterion (AIC) and Hannan-Quinn (HQ) lag length selection Criteria. Liew(2004) suggested Akaike's information criterion (AIC) gives the best result in the case of small sample (60 observations and below).consequently the study relied on AIC when ambiguity happens between AIC and HQ.

\subsubsection{Co-integration test}

Economically speaking, two variables will be co-integrated if they have a long run equilibrium relationship. If the variables are co-integrated it is possible to estimate long run relationship among the variables. In econometrics researches two commonly used co-integration approaches are Engle and Granger (1987, [32]) and Johansen and Juselius (1990) techniques of co-integration. Engle and Granger (1987) approach of testing co-integration is based on a two-step estimator. In the first step generating the residual series from the 
model and the second step is to use the generated residual to test co-integration among the variables. This makes the model to transmit errors obtained from the first step to the second step which makes the model unreliable to draw inferences. Consequently, the study used Johansen's Co-integration approach to assess long run relationship among non-stationary variables.

Johansen and Juselius (1990) procedures for Co-integration enables one to determine the number of existing co-integrated function in a single step process. Consider its generalisation to variables $n$, integrated of order $\mathrm{p}$ the specification of unrestricted VAR is given by:

$$
\mathrm{Y}_{\mathrm{t}}=\text { ? }+\mathrm{A}_{1} \mathrm{Y}_{\mathrm{t}-1}+\ldots+\mathrm{A}_{\mathrm{p}} \mathrm{Y}_{\mathrm{t}-\mathrm{p}}+\mathrm{U}_{\mathrm{t}}--------------(9)
$$

By differencing the equation (9) by $\mathrm{Y}_{\mathrm{t}-1}$ and taking the summation of the like terms the equation is reduced to the form:

$$
\Delta \mathrm{Y}_{\mathrm{t}}=\mu+\Pi \mathrm{Y}_{\mathrm{t}-1}+\sum_{\mathrm{i}=1}^{\mathrm{p}} \Gamma \mathrm{i} \mathrm{Y}_{\mathrm{t}-\mathrm{i}}+\mathrm{U}_{\mathrm{t}}----------------(10)
$$

Where $\Delta Y_{t}=Y_{t}-Y_{t-1}$ is the differencing operator, $\mu$ is the vector-valued mean of the series, $\Pi=\sum_{\mathrm{i}=1}^{\mathrm{p}}\left(\mathrm{A}_{\mathrm{i}}-\mathrm{I}\right)$ is the coefficient matrix for the first lag, Ai are the coefficient matrices for each lag, $\Gamma \mathrm{i}=-\sum_{\mathrm{j}=\mathrm{i}+1}^{\mathrm{p}} \mathrm{Aj}$ are the matrices for each differenced lag, and $\mathrm{Yt}$ and $\mathrm{U}_{\mathrm{t}}$ are $\mathrm{nx} 1$ vectors, and $\mathrm{A}$ is $\mathrm{nxn}$ matrix.

Coefficient matrix $\Pi$ can be reduced to rank $r<n$, using $n \times r$ matrices of $\alpha$ and $\boldsymbol{\beta}$ with rank $\mathrm{r}$ such that $\Pi=\alpha \boldsymbol{\beta}$ and $\boldsymbol{\beta}^{\prime} \mathrm{Y}_{\mathrm{T}}$ is stationary. Where $\mathrm{r}$ is number of co-integrating relationships, $\boldsymbol{\alpha}$ are adjustment parameters in the vector error correction model and each column of $\boldsymbol{\beta}$ is a co-integrating vector. In general, the rank of the matrix $\Pi$ is gives the number of co-integrated vector. Therefore, testing for co-integration focuses on checking for the rank of $\Pi$. Johansen proposed two alternative test statistics for the rank of $\Pi$ matrix using the following two test statistics:

$$
\begin{aligned}
& \lambda \operatorname{trace}(r)=-\mathrm{T} \sum_{r=r+1}^{n} \ln \left(1-\lambda_{i}\right) \\
& \lambda \max (r, r+1) \stackrel{=}{=} \operatorname{Tln}\left(1-\lambda_{r+1}\right)
\end{aligned}
$$

Where $\tilde{\lambda}$ denotes the estimated values of the characteristic roots obtained from the estimated $\Pi$, and $T$ is the number of observations.

The trace statistic tests the null hypothesis that the number of co-integrating vectors is less than or equal to $r$, against a general alternative hypothesis greater than $r$. In the case of maximum Eigen value test, the test is the null hypothesis that there exist $\mathrm{r}$ co-integrated vectors against the alternative hypothesis of $\mathrm{r}+1$.

\subsubsection{Error-correction model (ECM)}

Once Co-integration is proven to exist, the next step is construction of a dynamic error correction model (ECM) for short run relationship among the variables. The purpose of error correction model is to indicate the speed of adjustment from short run disequilibrium back to the long run equilibrium after a short run disturbance. If two variables $\mathrm{Y}_{\mathrm{t}}$ and $\mathrm{X}_{\mathrm{t}}$ are co-integrated, the standard error correction model (ECM) can be expressed as:

$$
\Delta \mathrm{Y}_{\mathrm{t}}=\gamma+\sum_{\mathrm{i}=1}^{\mathrm{n}} \alpha_{\mathrm{i}} \mathrm{X}_{\mathrm{t}-\mathrm{i}}+\mathrm{\alpha}_{1} E c t(-1)+\mathrm{U}_{\mathrm{t}}-----------------
$$

Where $\mathrm{Y}$ is constant of short run model, $\mathrm{X}_{\mathrm{t}-\mathrm{i}}$ is differenced stationary independent variable, $\alpha_{i}$ is coefficients of independent variables, and $\alpha_{1}$ the speed of adjustments to the long run equilibrium. The expected sign of $\alpha_{1}$ is negative and it should be significant. The higher the coefficient of the error term, the higher the speed of adjustment from the short run to the long disequilibrium.

\subsubsection{Stability test}

It has been noted that effectiveness of adopting the appropriate intermediate target depends on the stability of the money demand function. Consequently, the test of stability is applied to the residuals of the long run and short run models. The test was made with the help of the cumulative sum (CUSUM) and the cumulative sum of squares (CUSUMSQ) tests of stability introduced by Brown et al. (1975). If the plot of CUSUM and CUSUMSQ test statistics stays within the critical bounds of 5\% significance level represented by a pair of straight lines drawn at the $5 \%$ level of significance, the null hypothesis that all coefficients in the model are stable cannot be rejected. If CUSUM and CUSUMSQ cross these critical bounds at least once at 5\% significance level, then it was believed that the regression equation was unstable. 


\subsection{Unit toot tests}

\section{Empirical Results}

Table1 presents the Augmented Dickey-Fuller (ADF) unit root test for all variables used in the model. The result of the ADF test showed that all variables were non-stationary at level both with Intercept but no trend and With Intercept and trend. Each calculated t-value was less than ADF critical t-values at $5 \%$ significance level both with Intercept but no trend and With Intercept and trend. However, all variables become stationary at the first difference with Intercept but no trend at 5\% critical t-value of ADF. The result of ADF test is presented in the Table 1 below:

Table 1: Augmented Dickey-Fuller unit root Test with level and First Difference

\begin{tabular}{|c|c|c|c|c|c|}
\hline \multirow[t]{2}{*}{ Variable } & \multicolumn{2}{|l|}{ Levels } & \multicolumn{2}{|l|}{ First Difference } & \multirow[b]{2}{*}{ Decision } \\
\hline & $\begin{array}{l}\text { With Intercept } \\
\text { but no trend }\end{array}$ & $\begin{array}{l}\text { With Intercept } \\
\text { and trend }\end{array}$ & $\begin{array}{l}\text { With Intercept } \\
\text { but no trend }\end{array}$ & $\begin{array}{l}\text { With Intercept } \\
\text { and trend }\end{array}$ & \\
\hline & t-value & t-value & t-value & t-value & \\
\hline LnRM2 & 0.3608 & -1.8870 & $-4.3070^{*}$ & $-4.2810^{*}$ & $\mathrm{I}(1)$ \\
\hline LnRDGP & -3.1731 & -0.7437 & $-4.2525^{*}$ & $-7.8656^{*}$ & I (1) \\
\hline LnRt & -1.9371 & -1.9399 & $-5.4002^{*}$ & $-5.3338^{*}$ & $\mathrm{I}(1)$ \\
\hline LnEx & -0.5766 & -2.9613 & $-3.6840^{*}$ & $-3.6251 *$ & $\mathrm{I}(1)$ \\
\hline $\begin{array}{l}\text { ADF } \\
\text { critical } \\
\text { values at } 5 \\
\%\end{array}$ & -2.9511 & -3.5484 & -2.9540 & -3.5529 & \\
\hline
\end{tabular}

*The coefficient was significantly different from zero at $5 \%$ significance level

The above table revealed that all variables have unit root at level but become stationary at first difference. The results were also confirmed by taking the first differences of all variables which become stationary at first difference. These indicated that all variables are integrated of first order, I (1). Since the variables are integrated of the first order, the Johansen's co-integration approach was appropriate and used to analyse long run relationship among the variables.

\subsection{Co-integration test}

Given that all the series were integrated of first order, the Johansen (1988) and Johansen and Juselius (1992) tests were conducted to check the existence of the long run equilibrium relationship between real money demand and its determinants. The study employed Trace and maximal Eigen value tests to assess the existence of co-integrated equation and the number of co-integrated vectors. The result of the tests was shown in the Table 2 below:

Table 2: Results of Johnson's co-integration test

\begin{tabular}{|c|r|r|r|r|r|}
\hline \multicolumn{3}{|c|}{ Trace test } & \multicolumn{3}{c|}{ Maximum Eigen value test } \\
\hline $\begin{array}{c}\text { Hypothesized } \\
\text { No. of CE(s) }\end{array}$ & $\begin{array}{c}\text { Trace } \\
\text { Statistic }\end{array}$ & $\begin{array}{c}0.05 \\
\text { Critical Value }\end{array}$ & $\begin{array}{c}\text { Hypothesized } \\
\text { No. of CE(s) }\end{array}$ & $\begin{array}{c}\text { Max-Eigen } \\
\text { Statistic }\end{array}$ & $\begin{array}{c}\text { c.05 } \\
\text { Critical } \\
\text { Value }\end{array}$ \\
\hline None & 56.2024 & 47.85613 & None $*$ & 29.86426 & 27.58434 \\
\hline At most 1 & 26.3381 & 29.79707 & At most 1 & 17.30068 & 21.13162 \\
\hline At most 2 & 9.0374 & 15.49471 & At most 2 & 8.990665 & 14.2646 \\
\hline At most 3 & 0.0468 & 3.841466 & At most 3 & 0.04678 & 3.841466 \\
\hline
\end{tabular}

$*$ denotes rejection of the hypothesis at the 0.05 level

Both Trace test and Max-Eigen value test indicates 1 co-integrating equation at the 0.05 level

The test result in the table 2 showed that there exists one co-integrated equation in the model. The MaxEigen tests the null hypothesis of co-integrating equation was none, against one co-integrated equation. The value of Max-Eigen statistic was greater than the critical value at $5 \%$ significance level. Thus, the null hypothesis of no co-integration was rejected and alternative hypothesis of one co-integrating equation is accepted. Similarly, the Trace test also indicated one co-integrated equation at $5 \%$ level of significance. These implies that real money demand, real gross domestic product, saving deposit rate and average exchange rate have a long run equilibrium relationship. Consequently, the study proceeds to estimate long run model of money demand function in the following section.

\subsection{Long-run Money Demand Function}

Since the variables are co-integrated, the parameter estimate was made by employing Ordinary Least Square (OLS) on non-stationary time series data to assess the effect of the explanatory variables on real money 
demand. Thereafter, the test was made to investigate the parameter stability of the estimated long run model. The regression result of long run money demand function estimated by co-integration analysis is given in Table3 below:

Table3: Long run money demand regression result

\begin{tabular}{|c|c|c|c|c|}
\hline \multicolumn{5}{|c|}{ LnRM2 = -9.386 + 1.488 LnRGDP -0.016 LnRt + 0.657 LnEX } \\
\hline t-stat. & -4.79 & 8.73 & -0.77 & 5.51 \\
\hline prob. & 0.0153 & 0.0081 & 0.5342 & 0.0000 \\
\hline \multicolumn{5}{|c|}{$\begin{array}{l}\mathrm{R}^{2}=0.89 \text {, Adjusted } \mathrm{R}^{2}=0.88 \text {, S.E. of regression }=0.077 \text {, F-statistic }=85.27 \text { Prob(F- } \\
\text { statistic })=0.0000 \text {, Durbin-Watson stat }=2.19\end{array}$} \\
\hline
\end{tabular}

The regression result in Table 3 indicates that one percent increase in RGDP leads to 1.488 percent increase in money demand where as 1 percent increase in the exchange rate increases money demand by 0.657 percent. However, the sign of coefficient of interest rate is a negative implying that a one percent increase in the saving interest rate resulted in a 0.016 percent decrease in real money demand. As it can be seen from the probability value of the result RGDP and exchange rate have significant positive relationship with real money demand. Whereas the saving interest rate has negative and insignificant relationship at 5\% significance level. The insignificance of saving interest rate may be due to the low saving habit and underdevelopment of formal financial institution in the Ethiopian economy. These might made the demand for money insensitive to the interest rate by posing high transaction cost on liquidation and low opportunity cost of holding money. The long run money demand function indicated that real broad money demand had strong and highly significant relationship with real income and exchange rate where as saving interest rate was insignificant. The signs of coefficients are consistence with the expectation and conventional economic theory.

The goodness of fit of model as indicated by the value of adjusted $\mathrm{R}^{2}$ denoted that about $88 \%$ of the variations in real broad money demand are jointly explained by real GDP, saving interest rate and average exchange rate which indicated that the model fits the data well. The significant F-test further confirmed overall significance of the model at $5 \%$ significance level. The presence of autocorrelation in the residuals of the model was also tested using the Durbin-Watson statistics, the test valued of Durbin-Watson 2.19 fell within region of no autocorrelation in the Durbin-Watson table. Hence, the model is free from the first order autocorrelation problem.

The parameter stability of long run real broad money demand function was examined by employing Cumulative sum (CUSUM) and Cumulative sum of squares (CUSUMSQ) tests of parameter stability proposed by Brown et al. (1975). The plots of CUSUM and CUSUMSQ are shown in graph1and 2 below,

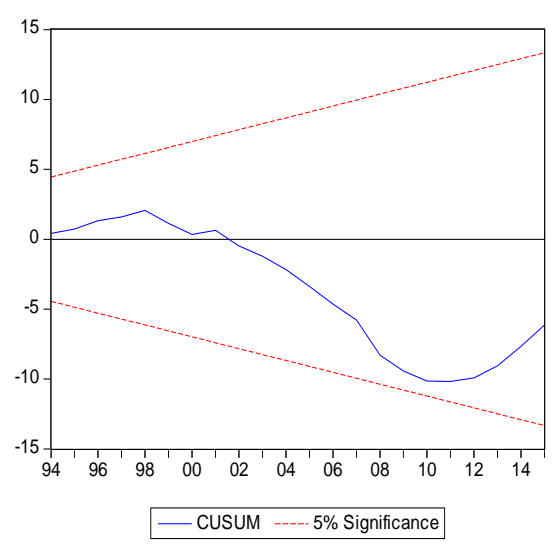

Graph 1: CUSUM test of LnRM2 model

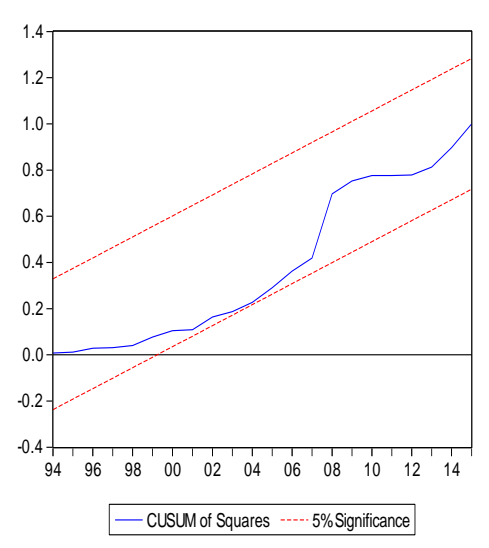

Graph 2: CUSUMQ test of LnRM2 model

The above graphs showed that the residuals of both Cumulative sum (CUSUM) and Cumulative sum of squares (CUSUMSQ) were remained within the critical bounds of the line drawn at 5 percent significance level. This indicated that parameters of long run real broad money demand function estimated in the Table 3 were stable for the period 1981 to 2014. Real broad money can be the appropriate indicator of monetary policy stance of Ethiopia. So targeting the growth rate of real broad money in consistent with the growth of real gross domestic product could be helpful for the conduct of monetary policy in Ethiopia. Thus, it can be concluded that National Bank of Ethiopia was effective in adopting Broad money supply (M2) as intermediate target of monetary policy framework. 


\subsection{Error Correct Model (ECM)}

The study further proceeded to examine the speed of disequilibrium adjustment from short run to the long run equilibrium by employing error correction model (ECM). The result of ECM was given in the table 4 below.

Table4: Error correction (ECM) result

\begin{tabular}{|c|c|c|c|c|}
\hline \multicolumn{5}{|c|}{ DLnRM2 = } \\
\hline t-stat. & $\begin{array}{ll}7.74 & 2.42 \\
\end{array}$ & 1.40 & -0.65 & -0.88 \\
\hline prob. & 0.0000 & 0.1694 & 0.5197 & 0.3841 \\
\hline
\end{tabular}

The short run regression results reported in Table 4 showed that real broad money demand was mainly determined by the growth of Real GDP. Real broad money demand had positive and significant relationship with the growth of real GDP. On the other hand, the coefficients of saving deposit rate and average exchange rate became insignificant in the shorter period. However, the coefficient of saving deposit rate turned to be negative. This may be due to persistence of real negative interest rate in the economy.

The coefficient of error-correction term is negative as expected, and it is insignificant at the 5 percent significance level. The error correction coefficient indicated that the speed of adjustment from short run disequilibrium to the long-run the steady state equilibrium is 5.6 percent. The result was also indicated that the speed of adjustment is insignificant at 5 percent level of significance. The slow adjustment from short run to the long run may be due to low saving rate and low financial innovation in Ethiopian economy which hinders the speed of monetary transmission mechanism. Low R2 further indicated that only 25 percent in the short run real broad money demand is affected by RGDP, saving deposit rate and average exchange rate jointly. However, significant F-statistic showed that the estimated short run model is overall insignificance at 5 percent significance level.

Furthermore, parameter stability test based on Cumulative sum (CUSUM) and Cumulative sum of squares (CUSUMSQ) of recursive residuals tests were made. If all the coefficients in the error correction model were stable, the CUSUM and CUSUMSQ plots would remain within 5 percent critical bounds drawn at 5 percent significance level. The plots of CUSUM and CUSUMSQ test are shown in the graphs 3 and 4 below:
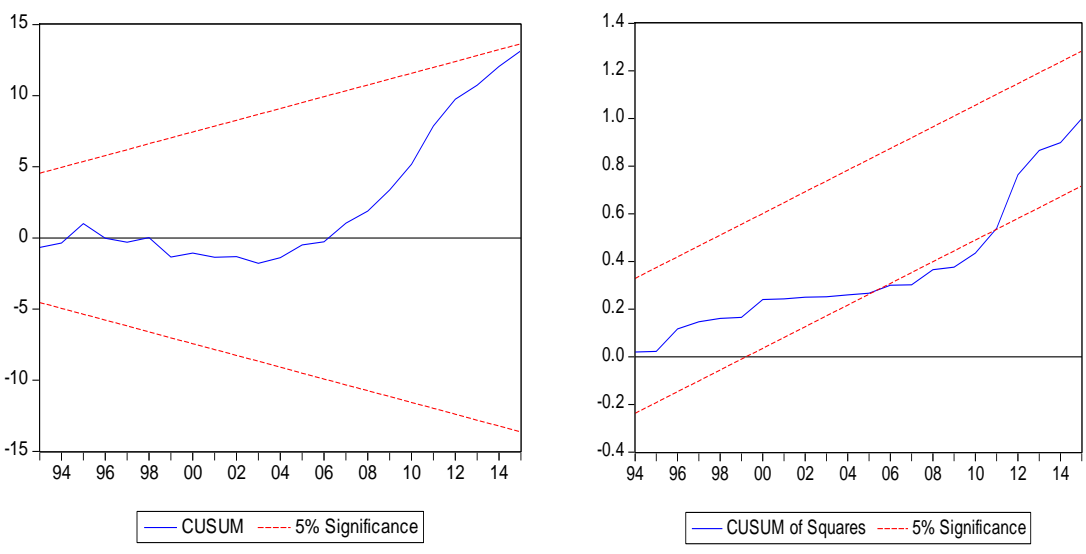

Graph 3: CUSUM test of DLnRM2 model Graph 4: CUSUMQ test of DLnRM2 model

As shown in graph 3 the plot of the CUSUM test had remained within the boundaries of the line drawn at 5 percent significance level. However, the plot of Cumulative sum of squares (CUSUMSQ) of recursive residuals in graph 4 crossed the boundary line drawn at 5 percent significant level. Thus CUSUMSQ test indicated the parameter instability of short run real broad money demand function for the sample period. However, the instability of short run real broad money demand function does not necessarily mean that monetary targeting is completely inappropriate in short run. Perhaps the National Bank of Ethiopia needs to consider other fiscal and monetary indicators to stabilize the economy. 


\section{Conclusions}

The study assesses the effectiveness of National Bank of Ethiopia in choosing appropriate intermediate target using annual data over the period from 1981 to 2014. The appropriateness of adopted intermediate target was examined using the stability of real broad money demand function. The study used Johansen (1988) and Johansen and Juselius (1992) co-integration approach in conjunction with error correction model (ECM). Before parameter estimation time series properties of real broad money demand (RM2), real GDP, saving deposit rate and average exchange rate was checked using Augmented Dickey-Fuller (ADF) unit root test. Augmented Dickey-Fuller (ADF) test indicated that all variables are stationary at first difference and integrated of orders one, I (1). Consequently, Johansen (1988) and Johansen and Juselius (1990) co-integration approaches were employed. Co-integration result of Trace and maximal Eigen value tests showed one co-integrated equation. The co-integration regression result also indicated that the real GDP and average exchange rate had positive and significant relationship with real broad money demand function at 5 percent significance level. In addition, the parameter stability test based on Cumulative sum (CUSUM) and Cumulative sum of squares (CUSUMSQ) confirmed the parameter stability despite the various change and developments in the economy. In Ethiopia where there is low financial sector integration and high inflation rate, interest rate targeting would send out wrong signals from the monetary sector. Hence, the viable policy option would be to continue with monetary targeting. In light of these findings, it is concluded that monetary targeting framework based on broad money supply (M2) can be appropriate intermediate target of monetary policy in Ethiopia and National Bank of Ethiopia was effective in choosing broad money supply (M2) as intermediate target.

Short run error correction result showed that real GDP growth had positive and significant relationship with real broad money demand whereas saving deposit rate and insignificant at 5 percent significance level. It is also indicated that only few variation 25 percent was explained by these variables jointly indicating that some other factors might have explained the variation in short run real broad money demand. Moreover, short run ECM model showed low speed of adjustment to ward long run equilibrium and evidence of parameter instability of short-run real broad money demand function. This implies that in short run National Bank of Ethiopia can better use multiple indicators approach in order to be able to consider a wider array of factors while using growth rate of broad money supply (M2) as one of reference indicator.

\section{References}

[1]. Poole, W., Optimal choice of monetary policy instruments in a simple stochastic macro model, Quarterly Journal of Economics , 84(May), 1970, 197-216.

[2]. Mishkin, F. S., The economics of money, banking, and financial markets( $7^{\text {th }}$ ed.), in: Clinton, D. (Ed.), (New York, United States of America: Pearson Addison Wesly,2004.

[3]. Friedman, B., Targets, instruments and indicators of monetary policy, Journal of Monetary Economics , 1(4), 1975, 443-473.

[4]. Volcker, P., The Role of Monetary Targets in an Age of Inflation, Journai of monetary Economics , 4 (2), 1978, 329-339.

[5]. Mohanty, D., Evidence of interest rate channel of monetary policy transmission in india(RBI No. 6), Mumbai, Reserve Bank of India, May 2012.

[6]. Faridi,M.Z. \& Akhtar,M.H., An estimation of money demand function in pakistan: Bound testing approach to Co-integration, Pakistan Journal of Social Sciences (PJSS) , 33 (1), 2013,11-24

[7]. John,O.,Soni,E.,Matthew, \& Onoriode, B., Empirical analysis of money demand function in Nigeria: 1986 - 2010 , International Journal of Humanities and Social Science , 3 (8), 2013,132-147.

[8]. Bhatta, S. R., Stablity of money demand function in Nepal, Banking Journal , 3 (2), 2013, 1-27.

[9]. Inoue,T., \& Hamori, S., An empirical analysis of money demand function in India(IDE No.166), Institute of Developing Economies, JETRO 3-2-2, Wakaba, Mihama-Ku, Chiba-Shi Chiba 261-8545, Japan, 2008.

[10]. Jiranyakul, K. \& Opiela, T.P., Instability of money demand: Recent evidence for Thailand, Modern Economy, 5 (88), 2014, 907913.

[11]. Sarwar, H., Sarwar,M. \& Waqas, M., Stability of money demand function in Pakistan, Economic and Business Review, 15 (3), 2013,197-212.

[12]. Kibret, H. Economic Reform and Stability of the Money demand function in Ethiopia, Staff Working Paper, Ethiopia economic research department, National Bank of Ethiopia,Addis Ababa, 2003.

[13]. Sterken, E., Demand for money and shortage in Ethiopia. Centre for development studies, University of Groningen, research report No. 199909, Groningen, Netherlands, 1999.

[14]. Johansen, S., Statisstical analyisis of cointegaration vectors, Journal of Economic Dynamics and Control , $12(3), 1988,231-254$.

[15]. Johansen, S. \& Juselius, K, Maximum likelihood estimation and inference on Co-integration with application to demand for money, Oxford Bulletin of Economics and Statistics, 52, 1990, 169-210.

[16]. Brown, R.L., Durbin, J. \& Evans, J.M., Techniques for testing the constancy of regression relations over time, Journal of the Royal Statistical Society, Series B (Methodological), 37(2), 1975, 149-192.

[17]. Nnanna, O. J., Monetary Policy Framework in Africa: The Nigerian Experience, Central Bank of Nigeria, Abuja, 2001.

[18]. Mohanty, D. How does the Reserve Bank of India conduct its monetary policy?, Indian Institute of Management (IIM), Lucknow,2011.

[19]. Anwar,S. Monetary policy framework in the SAARC region, paper presented at National seminar on Monetary policy framework in the SAARC region, Islamabad, June 2012, 14-16.

[20]. Gidey, B., Aksumite coins, currency and banking(Addis Ababa, Commercial Printing press, 1997).

[21]. Neube,M.,Lufumpa,C.L. \& Ndikumana,L.,Ethiopia's Economic growth Performance:Current Situation and Challenges, Economic Brief, 1 (5), 2010,1-5. 
[22]. Mohanty, D., Monetary policy framework in India: experience with multiple-indicators approach, Paper presented at Conference of the Orissa Economic Association, Baripada, Orissa, 21 February 2010.

[23]. Mohanty,B. \& Bhanumurthy, N. R., Exchange rate regimes and inflation: Evidence from India(NIPFP No.130),National Institute of Public Finance and Policy, New Delhi, 2014.

[24]. Kinight, M., Developing countries and the globalization of financial markets(IMF No. 98/105 ), Monetary and Exchange Affairs department, 1998.

[25]. Davis, R. G., Intermediate targets and indicators of monetary policy:- A critical survey, Federal Reserve Bank of New York, New York, United States of America, 1990.

[26]. Gichuki, J., Oduor, J. \& Kosimbei, G., The choice of optimal monetary policy instrument for Kenya, International Journal of Economics and Management Sciences, 1(9),2012, 1-23.

[27]. National Bank of Ethiopia (NBE), Monetary Policy Framework, 2009.

[28]. Fisher, I., Recent changes in price levels and their causes, American economic review: supplement, 1 (April), 1911, 37-45.

[29]. Keynes, J. M., The General Theory of Employment, Interest and Money (London: Macmillan, 1936).

[30]. Friedman, M., The quantity theory of money-A restatement, In: Friedman, M. (Ed.), Studies in the quantity theory of money. University of Chicago Press, Chicago, 1956, 3-21.

[31]. Rangarajan, C., Role of Monetary Policy, Economic and Political Weekly ,32 (52), 27 December 1997, $3325-3328$.

[32]. Engle,R.F. \& Granger, C. W. J., Co-integration and error correction: representation, estimation, and testing, Econometrica, $55(2), 1987,251-276$. 